\title{
Insulin-like growth factor 1 and 2 (IGF1, IGF2) expression in human microglia: differential regulation by inflammatory mediators
}

\author{
Hyeon-Sook Suh", Meng-Liang Zhao, Leandra Derico, Namjong Choi and Sunhee C Lee*
}

\begin{abstract}
Background: Recent studies in experimental animals show that insulin-like growth factor 1 (IGF1) plays a trophic role during development and tissue injury and that microglia are important sources of IGF1. However, little information is available regarding the expression, regulation, and function of IGF1 and related proteins in human brain cells. In the current study, we examined the expression of IGF1 and IGF2 in human microglia in vivo and in vitro.
\end{abstract}

Methods: Expression of IGF1 and IGF2 was examined by immunohistochemistry in post-mortem human brain sections derived from HIV+ and HIV- brains. In primary cultures of human fetal microglia, IGF1 and IGF2 mRNA and protein expression was examined by Q-PCR, ELISA, and Western blot analysis. Additionally, the role of IGF1 and IGF2 in neuroprotection was examined in primary human neuronal glial cultures.

Results: Immunohistochemistry of human brain tissues showed that nonparenchymal cells (vessels and meninges), as well as parenchymal microglia and macrophages were positive for IGF1, in both HIV encephalitis and control brains, while IGF2 was undetectable. Cultured microglia expressed IGF1 mRNA and produced pg/ml levels of IGF1 protein; this was significantly suppressed by proinflammatory mediators, such as lipopolysaccharide (LPS), poly(l:C), and IFNy. The Th2 cytokines IL-4 and IL-13 had no significant effect, but the CAMP analog (dibutyryl cAMP) significantly increased IGF1 production. In contrast, microglial IGF2 mRNA and protein (determined by Western blot) were upregulated by LPS. IGF1 receptor (IGF1R) immunoreactivity was predominantly expressed by neurons, and both IGF1 and IGF2 significantly protected neurons from cytokine (IL-1/IFNY) induced death.

Conclusions: Our study in human brain tissues and cells indicates that microglia are important sources of neurotrophic growth factors IGF1 and IGF2, and that microglial activation phenotypes can influence the growth factor expression. Importantly, our results suggest that chronic neuroinflammation and upregulation of proinflammatory cytokines could lead to neurodegeneration by suppressing the production of microglia-derived neuronal growth factors, such as IGF1.

Keywords: Brain, Cytokines, Growth factors, HIV, Human, IGF1, IGF2, Inflammation, LPS, Microglia

\footnotetext{
* Correspondence: hyeon-sook.suh@einstein.yu.edu; sunhee.lee@einstein.yu.edu Department of Pathology, Albert Einstein College of Medicine, Bronx, NY 10461, USA
} 


\section{Background}

Recent advances in microglial biology have revealed that microglia may have important homeostatic functions [1]. Microglia in normal brain are very active in surveillance of the normal neuronal environment and are the first cells to respond to any subtle changes [2]. Furthermore, not all activated microglia are toxic: microglia can contribute to neural repair and regeneration through phagocytosis and the production of anti-inflammatory and immunoregulatory mediators, as well as neuronal growth factors [3-6]. Recent studies in mice also indicate that microglia are distinct from monocytes in their origin, and that the two myeloid populations may have somewhat separate antigenic and functional profiles $[7,8]$. These findings together indicate that elucidating the microglial activation phenotypes and their regulatory mechanisms is important in understanding of the pathogenesis of diseases of the central nervous system (CNS).

In mice, the macrophage and microglial activation phenotypes are defined by the arginine metabolism pathway, with the classically activated phenotype (M1) characterized by the expression of inducible nitric oxide synthase (iNOS) and the alternatively activated phenotype (M2) by the expression of arginase-1 [9,10]. Macrophage M1 and M2 activation can typically be induced by exposure to Th1 (IFNY) and Th2 (IL-4 or IL-13) cytokines, respectively. The primary role of M2 macrophages is in wound healing and tissue repair, with arginase- 1 contributing to cell proliferation, resolution of inflammation, and remodeling of the extracellular matrix [9]. Considerably less information is available on the role of M2 microglia, but there is evidence that microglia produce neuronal growth factors IGF1, IGF2, and brain-derived growth factor (BDNF) [6,11-13]. To what extent the M1/M2 paradigm applies to human macrophages and microglia is uncertain, since neither iNOS nor arginase 1 is expressed in these cells $[14,15]$.

IGF1 has emerged as a crucial factor in the CNS; it is involved in normal cognitive function and successful aging, in addition to development [16-19]. IGF1 belongs to the insulin-like growth factor (IGF) family of proteins, to which the agonists IGF1 and IGF2, the receptors IGF1R and IGF2R, and several IGF-binding proteins (IGFBP1-7) belong [20-22]. Both IGF1 and IGF2 signal through the IGF1R leading to the growth and metabolic effects via the downstream PI3K/Akt pathway. IGF2R is not a signaling receptor but is instead involved in the capture and degradation of extracellular IGF2 (and IGF1) during development [23]. Although circulating blood IGF1 and IGF2 levels exert trophic effects on neurogenesis and neuronal survival $[18,20,24]$, CNS-derived or intrathecally derived IGF1 is also important in maintaining normal brain function [25]. It has been shown that local and systemic levels of IGF1 are altered in such CNS diseases as Alzheimer's disease [26]. IGF1, IGF2, IGFBP2, and IGFBP3 levels are also altered in individuals with HIV infection $[27,28]$. We have also recently reported that IGF2R is highly upregulated in HIV-infected CNS and that IGF2R is a novel IFN $\gamma$-inducible microglial protein that functions as a positive regulator of HIV infection [29]. Given these provocative findings and the significant species-dependent differences in neuroinflammatory mechanisms, we examined the regulation of IGF1 and IGF2 expression in human microglia in vivo and in vitro.

\section{Methods}

\section{Human brain sections and IGF1 and IGF2 immunohistochemistry}

Post-mortem brain sections with neuropathologic diagnosis of HIV encephalitis (HIVE) or minimal nonspecific changes (normal-appearing brains from both HIV+ and HIV - individuals) were obtained from the Manhattan HIV Brain Bank and processed for immunohistochemistry as previously described [29-31]. Briefly, sections were deparaffinized and underwent antigen retrieval in a citrate buffer at $95^{\circ} \mathrm{C}$ for $20 \mathrm{~min}$. The primary antibody used was a rabbit polyclonal antibody (prediluted) against fulllength recombinant human IGF1 (Abcam, catalog no. ab15320) based on its reaction on control sections. Positive controls for IGF1 included paraffin-embedded human fetal brain (strong staining of meninges and meningeal macrophages), as well as human fetal liver and the term placenta. Negative controls were (1) sections incubated with irrelevant antibodies and (2) sections incubated with antibodies pre-absorbed with the IGF1 peptide (Abcam). Sections were incubated overnight with the prediluted antibody at $4^{\circ} \mathrm{C}$ and then with anti-rabbit micropolymerlinked secondary antibody (ImmPress kit, Vector Laboratories) following the manufacturer's instructions. Color was developed using diaminobenzidine. IGF2 immunohistochemistry was performed using a rabbit antibody from Abcam (ab9574) that had previously been used to characterize human tumor specimens [32], employing the approaches described for IGF1. Briefly, the sections were incubated overnight with the IGF2 antibody (dilution of $1: 100)$ at $4^{\circ} \mathrm{C}$ and then with anti-rabbit micropolymerlinked secondary antibody (ImmPress kit) following the manufacturer's instructions.

\section{IGF1R immunocytochemistry}

The expression of IGF1R in mixed human CNS cell culture was determined by immunohistochemistry using anti-IGF1R antibody from R\&D systems (MAB391), as previously described [33]. Mixed human CNS cell cultures were fixed in $100 \%$ ice-cold methanol and were then permeabilized with $0.1 \%$ Triton X-100 detergent in PBS. Blocking for endogenous peroxidase and for nonspecific binding was performed with $3 \% \mathrm{H}_{2} \mathrm{O}_{2}$, followed by $5 \%$ 
normal goat serum (NGS) in PBS, each for $30 \mathrm{~min}$. Cultures were incubated with primary antibody (dilution of $1: 1000$ ) overnight at $4^{\circ} \mathrm{C}$ and then with the mouse micropolymer-linked secondary antibody (ImmPress kit) following the manufacturer's instructions. Color was developed using diaminobenzidine.

\section{Microglial culture}

Human CNS cell cultures were prepared from human fetal abortuses (gestational ages from 16 to 20 weeks) as previously described [34] with minor modifications. All tissue collection was approved by the Albert Einstein College of Medicine Institutional Review Board. Primary mixed CNS cultures were prepared by enzymatic and mechanical dissociation of the cerebral tissue followed by filtration through nylon meshes of $230-\mu \mathrm{m}$ and $130-\mu \mathrm{m}$ pore size. Single cell suspensions were plated at 1 to $10 \times$ $10^{6}$ cells per $\mathrm{ml}$ in DMEM (Cellgro, now ThermoFisher Scientific) supplemented with 10\% FBS (Gemini Bioproducts, Woodland, CA), penicillin $(100 \mathrm{U} / \mathrm{ml})$, streptomycin $(100 \mu \mathrm{g} / \mathrm{ml})$ and Fungizone $(0.25 \mu \mathrm{g} / \mathrm{ml})$ (complete medium) for 2 weeks, and then microglial cells were collected by aspiration of the culture medium. Monolayers of microglia were prepared in 60-mm tissue culture dishes at $1 \times 10^{6}$ cells per $5 \mathrm{ml}$ medium (for Q-PCR) or in 96well tissue culture plates at $4 \times 10^{4}$ per $0.1 \mathrm{ml}$ medium (for ELISA). Four to eighteen hours later, cultures were washed to remove nonadherent cells (neurons and astrocytes). Microglial cultures were highly pure, and consisted of $>98 \% \mathrm{CD}^{+} 8^{+}$cells.

\section{Culture stimulation}

The culture medium was changed to low-serum medium (DMEM plus $0.05 \%$ FBS) before cell stimulation to reduce potential effects from other growth factors. Lipopolysaccharide (LPS) and poly(I:C) were purchased from Sigma-Aldrich (St. Louis, MO) and used at $100 \mathrm{ng} / \mathrm{ml}$ and $10 \mu \mathrm{g} / \mathrm{ml}$, respectively. Recombinant human cytokines (IL-1 $\beta$, IFN $\gamma$, IL-4, and IL-13) were purchased from Peprotech (Rocky Hill, NJ) and were used at $10 \mathrm{ng} / \mathrm{ml}$, unless otherwise stated. Microglia were also stimulated with dibutyryl adenosine 3/, 5/-cyclic monophosphate (db cAMP, Sigma-Aldrich) at 0.5 to $5 \mathrm{mM}$, or with recombinant growth hormone (R\&D Systems, catalog no. 1067-GH) at 1 to $100 \mathrm{ng} / \mathrm{ml}$. Cells were stimulated and harvested as specified in individual experiments.

\section{Q-PCR}

Quantitative real-time reverse-transcription PCR (Q-PCR) was performed as described [35,36], using porphobilinogen deaminase (PBDA) as an internal control. Briefly, total RNA was extracted with TRIzol and PCR performed using a SYBR green PCR mix and the ABI Prism 7900HT system (Applied Biosystems). All values were expressed as the increase relative to the expression of PBDA. The median value of the replicates for each sample was calculated and expressed as the cycle threshold $\left(\mathrm{C}_{\mathrm{T}}\right.$; cycle number at which each PCR reaches a predetermined fluorescence threshold, set within the linear range of all reactions): $\Delta C_{T}$ was calculated as $C_{T}$ of endogenous control gene (PBDA) minus $\mathrm{C}_{\mathrm{T}}$ of target gene in each sample. The relative amount of target gene expression in each sample was then calculated as $2^{\Delta \mathrm{CT}}$. Fold change was calculated by dividing the value $\left(2^{\Delta \mathrm{CT}}\right)$ of test sample by the value $\left(2^{\Delta \mathrm{CT}}\right)$ of control sample (control $=1$ ). Primers for Q-PCR were IGF1: forward TGGATGCTCTTCAGTTCGTG, backward TGGTAGATGGGGGCTGATAC; IGF2: forward ACACC CTCCAGTTCGTCTGT, backward GGGGTATCTTGGG GAAGTTGT; IGF2R: forward GAAGGTGAAGGTCGG AGT, backward GAAGATGGTGATGGGATTTC; TNF $\alpha$ : forward GGCGTGGAGCTGAGAGATAAC backward, GG TGTGGGTGAGGAGCACAT.

\section{ELISA}

The levels of IGF1 and IGF2 were determined using human IGF1 antibody DuoSet (catalog no. DY291, detection limit $\sim 50 \mathrm{pg} / \mathrm{ml}$ ) purchased from R\&D Systems (Minneapolis, MN) and IGF2 ELISA kit (catalog no. RHF350CK, detection limit $300 \mathrm{pg} / \mathrm{ml}$ ) from Antigenix America (Huntington Station, NY) respectively, following the manufacturer's instructions. Briefly, polystyrene 96-well plates (Nunc) were pre-coated overnight at room temperature with specific capture $\mathrm{Ab}$, then blocked with 1\% BSA in buffer A (PBS plus 0.1\% Tween 20) for $2 \mathrm{~h}$ at room temperature. The plates were then incubated with standard IGF dilutions or cell culture media for $2 \mathrm{~h}$ at room temperature, washed with buffer $\mathrm{A}$, and incubated with the biotinylated detection $\mathrm{Ab}$ for $2 \mathrm{~h}$ at room temperature. After the second wash, the plates were incubated with HRP-streptavidin for $30 \mathrm{~min}$ at room temperature and washed again. The signal was developed after addition of 3,3'5,5'-tetramethylbenzidine-peroxidase EIA kit (Bio-Rad) for 4 to $10 \mathrm{~min}$ and the reaction was stopped by $1 \mathrm{M} \mathrm{H}_{2} \mathrm{SO}_{4}$. A microplate reader (Dynex Technologies) was used to detect the signals at $450 \mathrm{~nm}$ with correction at $530 \mathrm{~nm}$.

\section{Western blot}

Western blot analysis was performed as previously described [11,35] with minor modifications. Briefly, cell cultures in $60 \mathrm{~mm}$ dishes were scraped into lysis buffer (PBS plus protease inhibitors from Sigma) at various time points. Thirty micrograms of protein was separated by 4 to $20 \%$ TGX polyacrylamide gel electrophoresis and then transferred to a polyvinylidene difluoride membrane. The blots were blocked in PBS-0.1\% Tween-20 containing $5 \%$ nonfat milk and then incubated with antibodies at $4^{\circ} \mathrm{C}$ for $16 \mathrm{~h}$. Primary antibodies were against 
rabbit polyclonal IGF2 from Abcam (ab9574), applied at a dilution of 1:500. An antibody against $\beta$-actin (SigmaAldrich, A2228) or vinculin (Santa Cruz, SC5573) was used as the loading control. The secondary antibody was either horseradish peroxidase-conjugated anti-mouse or anti-rabbit IgG (Pierce Biotechnology, Rockford, IL) and was used at 1:1,000 for $1 \mathrm{~h}$ at room temperature. Signals were developed using enhanced chemiluminescence (Pierce Biotechnology). Densitometric analysis was performed using Scion NIH Image software (Scion, Frederick, MD).

\section{Preparation of mixed CNS cell cultures and neurotoxicity assay}

Mixed neuronal and glial cultures were generated by replating the initial CNS cell cultures once into 96-well tissue culture plates, as previously described [34,37]. Cultures were kept as monolayers in DMEM with $10 \%$ FBS and antibiotics and used at approximately 4 to 6 weeks in vitro. Cultures were stimulated with IL-1/IFNY at $10 \mathrm{ng} / \mathrm{ml}$ in low-serum medium (DMEM + 0.05\% FBS) for $72 \mathrm{~h}$ to induce neurotoxicity with or without recombinant human
IGF1 (catalog no. 100-11) and IGF2 (catalog no. 100-12) purchased from Peprotech (NJ, Rocky Hill) at $10 \mathrm{ng} / \mathrm{ml}$. Neurotoxicity assay was performed by vital dye exclusion (trypan blue) and microtubule-associated protein 2 (MAP2) immunostain, as previously described [37-39].

\section{Statistical analysis for tissue culture studies}

Normalized data (fold change over control) from different brain cases were compared using one sample $t$ test. For multiple comparisons, one-way analysis of variance (ANOVA) with Dunnett's multiple comparison tests was performed. All statistics were performed using the GraphPad Prism 5.0 software.

\section{Results}

IGF1 is expressed in microglia and macrophages in human CNS

Results of IGF1 immunohistochemistry in human CNS using the HIV+ and HIV- brains are summarized in Figure 1 and in Table 1. In all of these brains, the main IGF1 immunoreactivity in the brain parenchyma was

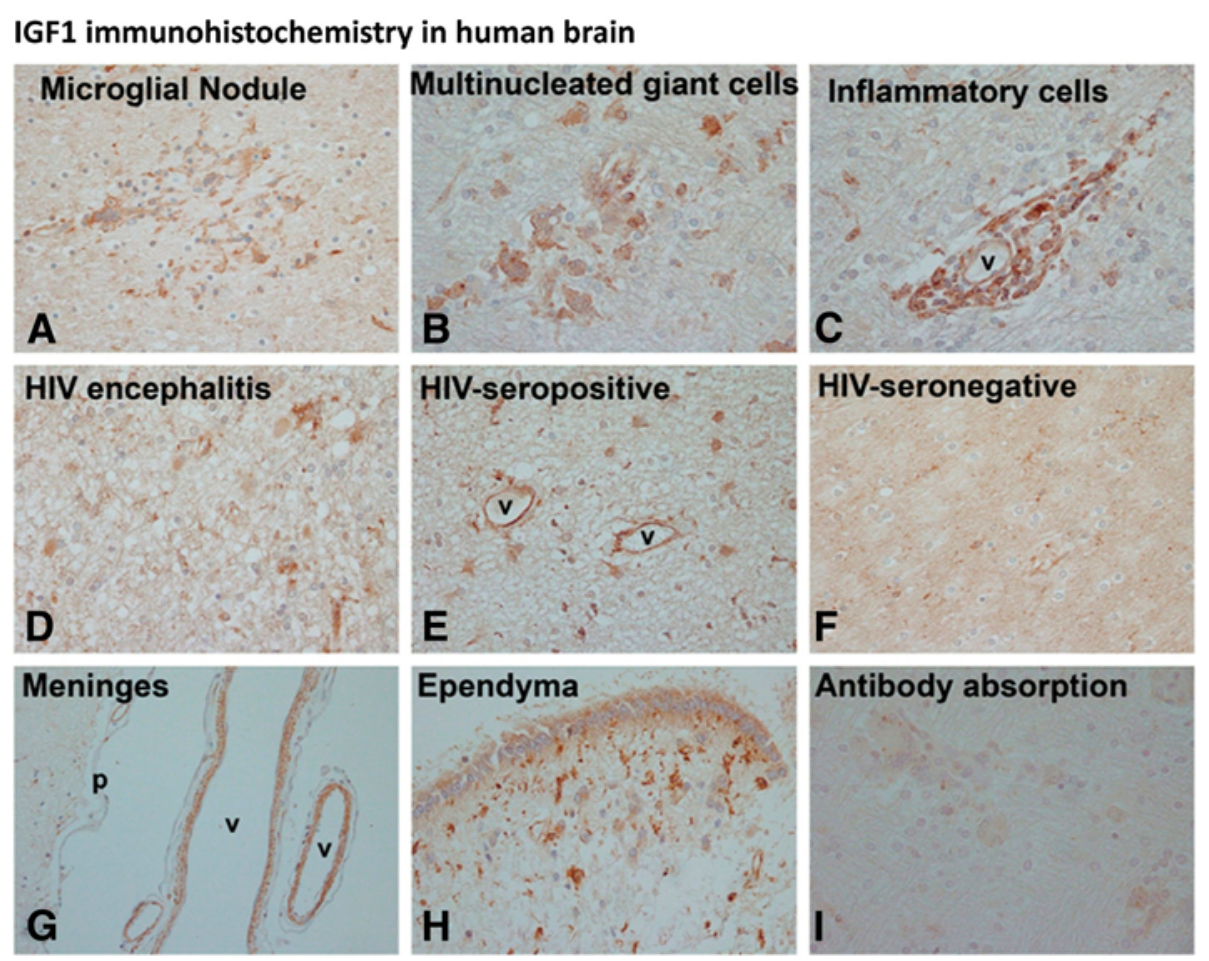

Figure 1 IGF1 is expressed in human brain. IGF1 immunohistochemistry was performed on paraffin-embedded post-mortem human brain sections from HIV+ and HIV- individuals. IGF1 staining was found in microglial nodules and multinucleated giant cells as well as perivascular inflammatory cells (perivascular lymphocytes and macrophages) in HIV encephalitis brains (A-C). Examples of diffuse parenchymal microglial cell staining are shown in HIV encephalitis, HIV+ and HIV- brains (D-F). Additional IGF1+ cell types included occasional endothelial cells (E: $\vee=$ vessels) and astrocytes (in E). IGF1 staining was also noted in the meninges (G) in vascular smooth muscle cells ( $v=$ vessels), as well as in ependymal cells $\mathbf{( H )}$ in some brains (note strong microglial staining in the subependymal area in $\mathrm{H}$ ). Controls included incubation of sections with the peptide pre-absorbed antibody, which abrogated IGF1 immunoreactivity (I). 
Table 1 IGF1 expression in human brain

\begin{tabular}{|c|c|c|c|c|c|c|c|}
\hline Pathology & Case number & Microglia & $\begin{array}{l}\text { Multinucleated } \\
\text { giant cells }\end{array}$ & $\begin{array}{l}\text { Microglial } \\
\text { nodules }\end{array}$ & $\begin{array}{l}\text { Inflammatory } \\
\text { cells }^{\mathrm{a}}\end{array}$ & $\begin{array}{l}\text { Vessels and } \\
\text { meninges }\end{array}$ & Other $^{c}$ \\
\hline \multirow[t]{6}{*}{ HIV encephalitis $^{d}$} & Case 23 & + & + & + & \pm & + & ependyma \\
\hline & Case 1 & + & + & - & + & + & ependyma \\
\hline & Case 3 & \pm & + & - & + & + & - \\
\hline & Case 20 & + & + & + & + & + & ependyma, neurons \\
\hline & Case 22 & + & + & + & + & + & - \\
\hline & Case 9 & + & + & + & \pm & + & - \\
\hline \multirow[t]{4}{*}{ No encephalitis ${ }^{e}$} & Case 11 (HIV+) & + & $N A^{f}$ & $N A^{f}$ & $N A^{f}$ & + & - \\
\hline & Case $12(\mathrm{HIV}+)$ & + & $N A^{f}$ & $N A^{f}$ & $N A^{f}$ & + & - \\
\hline & Case $21(\mathrm{HIV}+)$ & + & $N A^{f}$ & $N A^{f}$ & + & + & astrocytes \\
\hline & Case 18 (HIV-) & + & $N A^{f}$ & $N A^{f}$ & $N A^{f}$ & + & neurons \\
\hline
\end{tabular}

${ }^{a}$ Inflammatory cells were mononuclear cells (lymphocytes, monocytes and macrophages) present in the brain parenchyma or in perivascular spaces; ${ }^{\mathrm{b}}$ IGF1 immunoreactivity was regularly associated with vessels in both brain parenchyma and meninges. Staining was present in smooth muscle cells, as well as in some endothelial cells. Some meningeal arachnoid cells and macrophages were also occasionally IGF1 positive; ${ }^{\circ}$ Other parenchymal IGF1positive cells included ependymal cells, occasional astrocytes or rarely even neurons; ${ }^{d} \mathrm{HIV}$ encephalitis sections had characteristic pathology on H\&E consisting of MGCs, microglial nodules, activated microglia and macrophages, and mononuclear inflammatory cell infiltration; ${ }^{~}$ Control brain sections had no significant pathology on H\&E; ${ }_{\mathrm{f}}^{\mathrm{N} A}$ (not applicable, since no inflammatory cells were present).

detected in myeloid cells (microglia and macrophages). For example, microglial nodules and multinucleated giant cells (MGCs) (from HIV-infected microglia and macrophages), the hallmark lesions of HIVE, were positive for IGF1 (Figure 1A,B). In addition, perivascular macrophages and inflammatory cells were also positive (Figure 1C). Parenchymal ramified microglial cells were IGF1 positive in all three conditions (HIVE, $\mathrm{HIV+}$, and HIV- brains) (Figure 1D-F). In addition, occasional endothelial cells and vascular smooth muscle cells within the brain (Figure 1E) and meninges (Figure 1G), as well as ependymal cells (Figure 1H) and rare astrocytes (Figure 1E) or neurons (not shown) were IGF1-positive. A semiquantitative assessment of IGF1 immunoreactivity is presented in Table 1. These results together suggest that cells of myeloid lineage (microglia and macrophages) are the predominant IGF1-expressing cells in human CNS parenchyma, but other cells (including meningeal and vessel-associated cells) also contribute to the IGF1 production.

We also attempted to determine IGF2 expression in human CNS by immunohistochemistry. A rabbit polyclonal antibody from Abcam (ab9574), which had previously been used to characterize human tumor specimens [32], was utilized in this study. Using the approach described for IGF1 immunohistochemistry, we examined the same control and HIV+ brain sections. All brain sections showed diffuse background-like staining combined with some nuclear staining (data not shown). The nuclear staining was also observed in cultured microglia (not shown). Attempts with additional commercial IGF2 antibodies were equally unsuccessful, indicating either that the antibodies are not suitable for tissue immunohistochemistry or that there is no significant IGF2 expression in human CNS (see Discussion).
Regulation of cultured human microglial IGF1 and IGF2 mRNA expression by inflammatory mediators (Q-PCR)

We next examined the expression of IGF1 and IGF2 in primary human microglial cultures. The expression of IGF2R, which we previously reported to be an IFN $\gamma$-inducible novel microglial protein [29], and the proinflammatory cytokine TNF $\alpha$ were also examined simultaneously in the same cultures. Microglia were stimulated with Th1 (IFN $\gamma$ ) or Th2 (IL-4, IL-13) cytokines, the toll-like receptor (TLR) ligands (LPS or poly(I:C)), or medium alone (DMEM + $0.05 \% \mathrm{FBS}$ ) for $6 \mathrm{~h}$ at indicated doses, then mRNA expression was determined by Q-PCR. The mRNA levels for IGF1, IGF2, IGF2R, and TNF $\alpha$ were expressed relative to those in unstimulated cultures (control $=1)$. Results pooled from several microglial cultures derived from different brain cases are shown in Figure 2. They indicate that IGF1 mRNA expression was slightly suppressed by IFNy but was more potently suppressed by LPS and poly(I:C) (Figure 2A). The effects of IL-4 and IL-13 were variable, with no significant effects across different cases. In contrast, IGF2 mRNA was significantly upregulated by LPS (Figure 2B), while IFN $\gamma$, IL-4, IL-13, and poly(I:C) had no significant effect. IGF2R mRNA was upregulated by IFN $\gamma$ only (Figure 2C), consistent with our previous results obtained with Western blot [29]. TNF $\alpha$ mRNA was determined to control for the efficacy of cytokine and TLR ligands, and this showed that LPS and poly(I:C) potently induced TNF $\alpha$ mRNA, as expected. In addition, a small but significant induction and reduction of TNF $\alpha$ mRNA was also observed by IFN $\gamma$ and IL-4/IL-13, respectively (Figure 2D, see Discussion). These results together show that the expression of IGF1, IGF2, IGF2R, and TNFa is distinctly regulated in human microglia. 


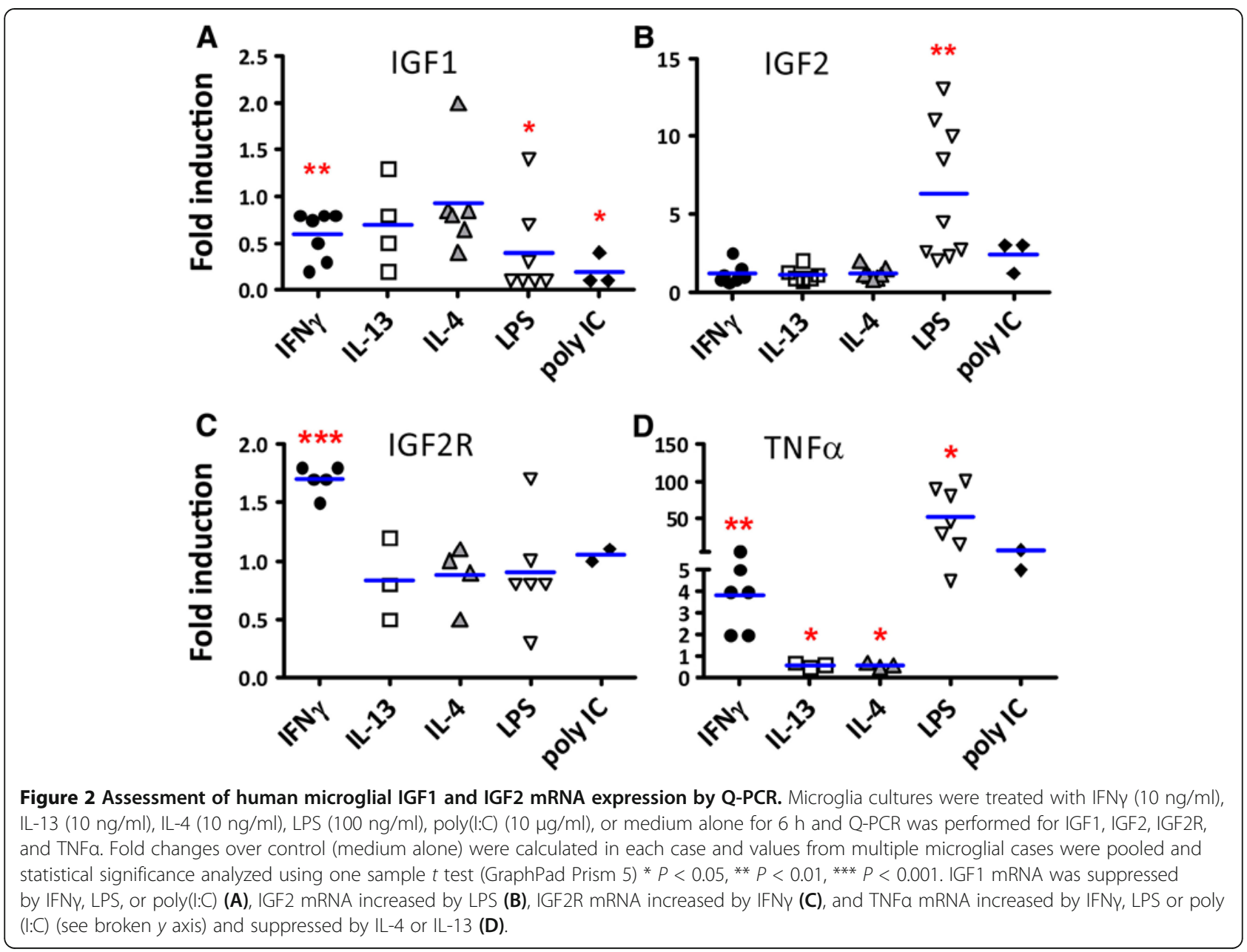

Regulation of human astrocyte IGF1 and IGF2 mRNA expression by inflammatory mediators (Q-PCR)

We have also performed Q-PCR analysis of astrocyte cultures for comparison with microglia. Since human astrocytes do not respond to LPS but respond maximally to IL-1, we treated cultures with the Th1 cytokine (IFN $\gamma$ ) with and without IL-1 $\beta$, the Th2 cytokines (IL-4, IL-13), and the TLR ligand poly(I:C). The mRNA levels for IGF1, IGF2, and TNF $\alpha$ were determined and expressed relative to those in unstimulated cultures. Results from two different astrocyte cases are shown in Figure 3. Astrocyte IGF1 mRNA levels were not significantly changed by inflammatory mediators, while IGF2 mRNA levels were highly upregulated by IL $-1 \beta( \pm$ IFN $\gamma)$. TNF $\alpha$ was also highly induced by IL- $1 \beta / \mathrm{IFN} \gamma$, as previously reported. Both IL-1 $\beta$ and poly(I:C) had lesser effects, while IL-4 and IL-13 had no effect. IGF1 was undetectable in astrocyte culture supernatants (not shown). These results suggest that while astrocyte IGF1 expression might be insignificant, IGF2 might be upregulated under inflammatory conditions (see Discussion).
Regulation of human microglial IGF1 protein expression (ELISA)

We next performed ELISA for IGF1 production in human microglia. Microglial cultures were treated with various cell stimuli as shown for Q-PCR analysis, and the $24 \mathrm{~h}$ cultures supernatants were subjected to ELISA assay (R\&D DuoSet, sensitivity $\approx 50 \mathrm{pg} / \mathrm{ml}$ ). As shown in Figure 4A, the amounts of IGF1 protein in microglial supernatants were relatively low $(\sim 100 \mathrm{pg} / \mathrm{ml}$ range $)$ and the samples stimulated with proinflammatory mediators showed even lower levels. Microglial IGF1 levels were suppressed by IFN $\gamma$ or LPS, but IL-4 had no effect. The IFN $\gamma$ effect was dose-dependent, with suppressive effects shown only in high concentrations (100 ng/ml or above). In addition to inflammatory mediators, we tested additional compounds that have been shown to modulate IGF1 expression in other cell types [40,41]. Of these, the cAMP analog db cAMP (0.5 to $5 \mathrm{mM}$ ) increased microglial IGF1 production (Figure 4B). However, growth hormone (1 to $100 \mathrm{ng} / \mathrm{ml}$ ), the primary inducer of hepatic IGF1, had no effect (data not shown). These results 


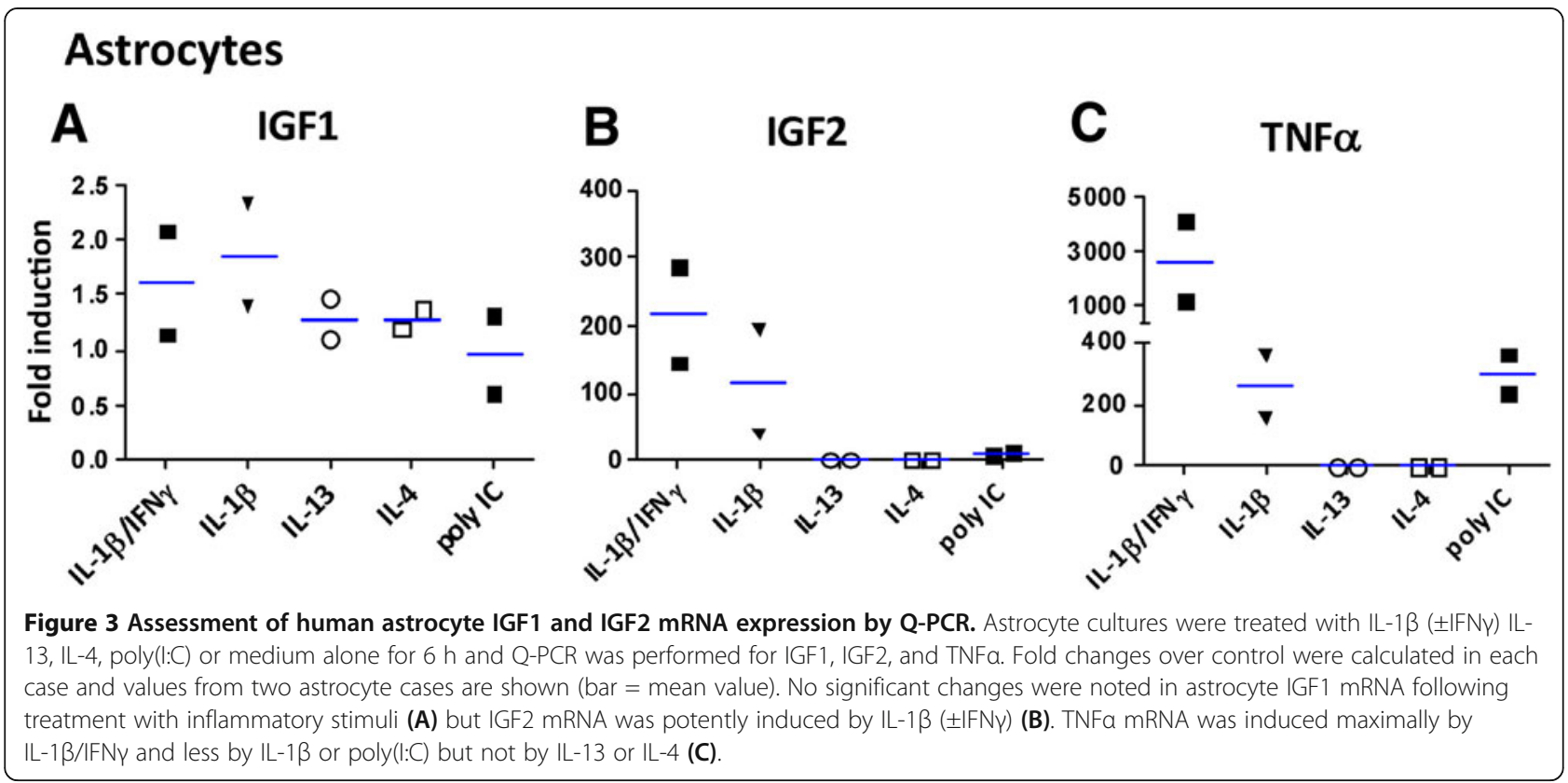

together show that IGF1 expression is cell-specific and that human microglial IGF1 production is suppressed by proinflammatory mediators (IFN $\gamma$ or LPS), is not significantly modulated by IL-4, and is increased by cAMP (see Discussion).

\section{Regulation of microglial IGF2 protein expression}

We next attempted to determine the IGF2 protein levels in microglial cultures by ELISA. A commercially available ELISA that is compatible with culture supernatants was obtained from Antigenix America but this had a detection limit of $\sim 300 \mathrm{pg} / \mathrm{ml}$. Other commercial IGF2 ELISAs (Alpco Diagnostics or Diagnostic System Laboratories, for example) were not intended for tissue culture fluid assays and had a similar low sensitivity. Microglial culture IGF2 levels were not detectable using these assays (not shown), perhaps because of the assays' low sensitivity. Therefore, we next determined microglial IGF2 expression using Western blot analysis (Figure 5). Cell lysates were separated in a 4 to $20 \%$ TGX polyacrylamide gradient gel and the blot was probed with a rabbit anti-IGF2 antibody (Abcam), as described. Representative results with densitometric ratios are shown in Figure 5 . A single band of $\approx 7.5 \mathrm{kDa}$ (consistent with the molecular mass of IGF2) was detected in microglial cultures stimulated with LPS but not with IL-4, IL-13, IFN $\gamma$, or poly(I:C) (Figure 5A). Time course analyses showed that IGF2 upregulation by LPS was transient at 24 $\mathrm{h}$ (Figure 5B). These results together demonstrate that IGF2 expression in human microglia is upregulated by LPS.

\section{Expression of IGF1 receptor (IGF1R) in mixed neuronal glial cultures}

Both IGF1 and IGF2 signal through the IGF1R, suggesting that both IGFs could promote neuronal survival by activating the downstream Akt pathway, but a direct demonstration of IGF peptides' neurotrophic effects is rare. We thus examined whether IGF1 and IGF2 confer neuroprotection in our well-characterized cytokine-induced neuronal death assay using primary human neuronal glial cultures [34,37]. First, we examined IGF1R expression by immunocytochemistry of mixed human fetal CNS cultures using an antibody that detects the extracellular domain of human IGF1R (R\&D Systems). As shown in Figure 6, IGF1R expression was found predominantly in neurons (small process-bearing cells) and the immunoreactivity was localized to the cell membrane. Glial cells did not appear to have significant IGF1R immunoreactivity. Stimulation of the mixed cultures with various inflammatory mediators did not affect the amount of IGF1R immunoreactivity appreciably (Figure 6).

IGF1 and IGF2 rescue human fetal neurons from cytokineinduced death

We next investigated whether IGFs have the neuroprotective effects in our mixed human fetal CNS cultures, following a published protocol [34,37]. Briefly, cultures consisting primarily of neurons and astrocytes and a minor population of microglia were stimulated with IL$1 \beta / \mathrm{IFN} \gamma$ (10 $\mathrm{ng} / \mathrm{ml}$ each) for 3 days to determine the extent of neuronal death. We examined the role of IGFs by treating the cultures with either IGF1 or IGF2 at $10 \mathrm{ng} / \mathrm{ml}$ for $2 \mathrm{~h}$ prior to cytokine stimulation. Three days later, neuronal death was determined by vital dye exclusion (Figure 7A) or MAP2 immunostain (Figure 7B and $\mathrm{C}$ ). The results show that IL- $1 \beta / \mathrm{IFN} \gamma$-induced neuronal death was significantly reduced by addition of recombinant IGF1 or IGF2. Higher concentrations of 


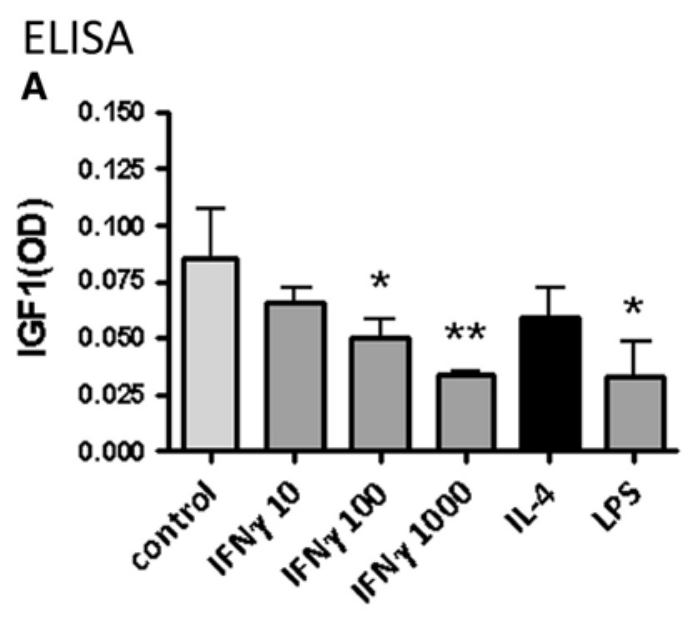

B

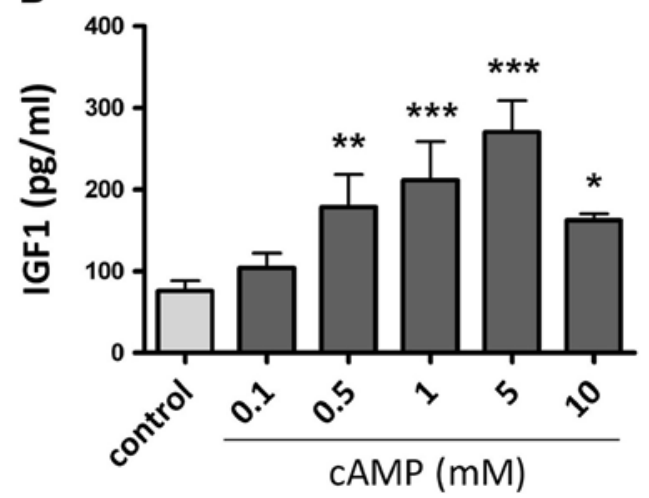

Figure 4 IGF1 protein production by microglia as assessed by ELISA. Microglia in triplicate cultures were stimulated with IFNY $(10,100$, and $1000 \mathrm{ng} / \mathrm{ml})$, IL-4 $(10 \mathrm{ng} / \mathrm{ml})$, LPS $(100 \mathrm{ng} / \mathrm{ml})$, or medium alone (control) for $24 \mathrm{~h}$ and culture supernatants were analyzed for IGF1 protein content by ELISA (A). Microglial cultures were also exposed to different doses of db CAMP (0 to $10 \mathrm{mM}$ ) (B) as shown and culture supernatants were analyzed for IGF1 by ELISA. Microglial culture IGF1 levels were low (at the lower detection range of the ELISA) and they were further decreased by proinflammatory stimulants. Mean \pm SD, One-way ANOVA with Dunnett's multiple comparisons * $P<0.05$, ${ }^{* *} P<0.01$, ${ }^{* *} P<0.001$.

IGFs $(100 \mathrm{ng} / \mathrm{ml})$ or the combination of IGF1 and IGF2 did not confer further protection (data not shown).

\section{Discussion}

Our study demonstrates that microglia and macrophages are the main expressors of IGF1 in human CNS parenchyma. In addition, a number of other cell types located in the subarachnoid space, the cerebrospinal fluid (CSF) brain barrier, and the blood brain barrier (such as meninges, ependymal cells, endothelial cells, and vascular smooth muscle cells) expressed IGF1 immunoreactivity. These results are consistent with the previous studies of developing rodents and human brains, which showed that IGF1 mRNA is predominantly expressed by CNS mesenchymal cells (meninges, enclosed vessels, macrophages, choroid plexus,

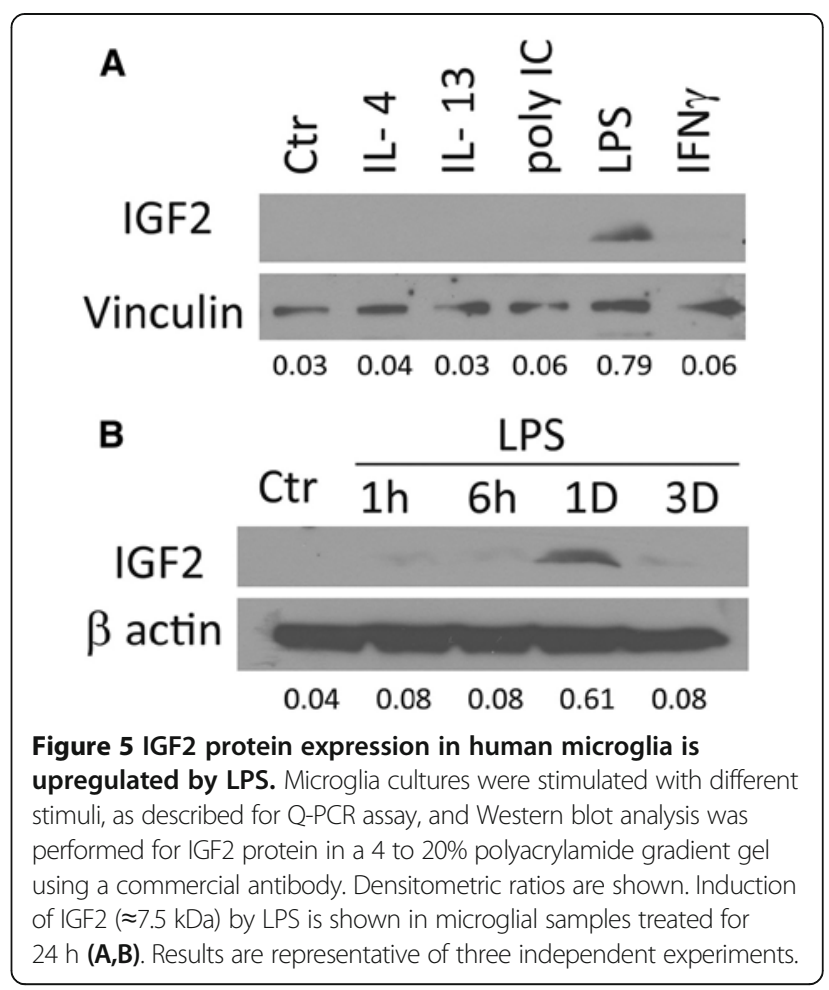

and so on) [42-44]. Additional recent rodent studies of experimental CNS conditions reported that microglia (and astrocytes in some instances) express IGF1 [45-48]. Less information is available on IGF2, but there are reports that show that microglia in developing and injured CNS express IGF2 protein [49-51]. In addition, intracranial mesenchymal cells serve as sources of IGF2

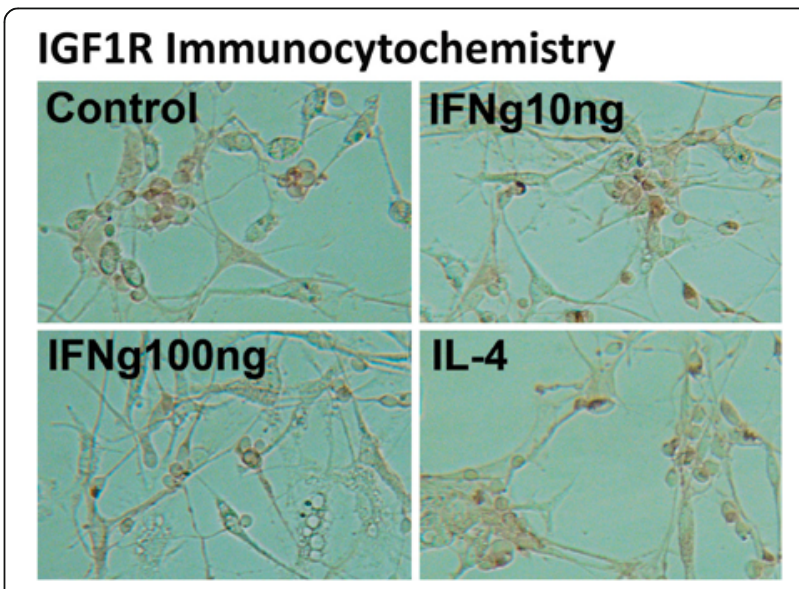

Figure 6 IGF1R expression in human fetal neurons. Mixed neuronal glial cultures stimulated for $24 \mathrm{~h}$ with IFNY (10 or $100 \mathrm{ng} / \mathrm{ml}$ ), IL-4 (10 ng/ml), or LPS (not shown) or not (Control) and immunostained for IGF1R using a commercial antibody. IGF1R immunoreactivity (brown) was selectively expressed in small processbearing cells in these cultures (neurons) without appreciable differences in the expression levels among various culture conditions. 

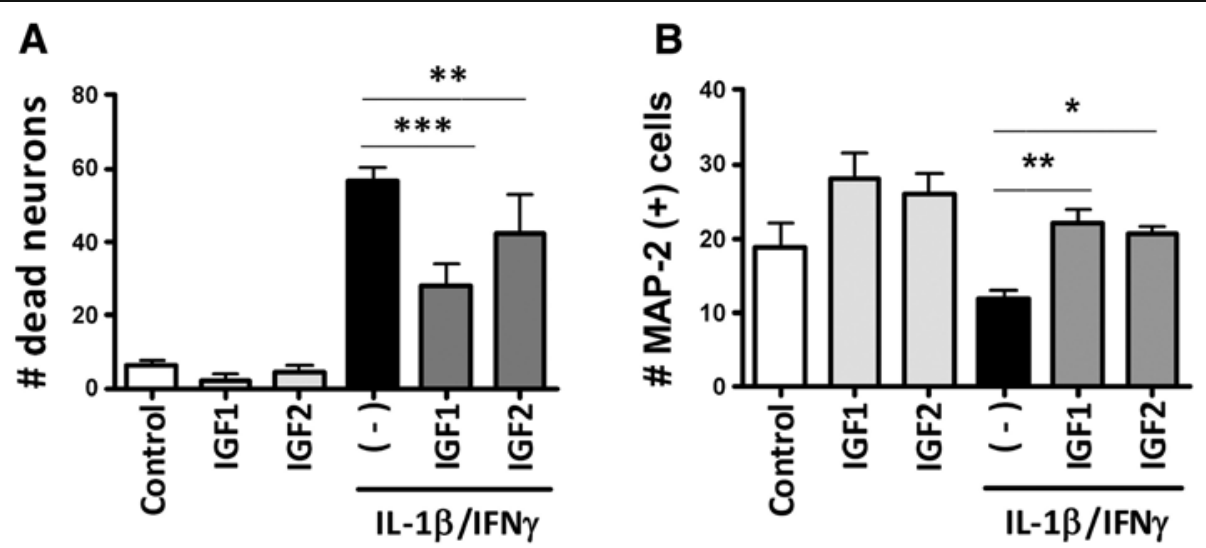

C MAP-2 immunocytochemistry
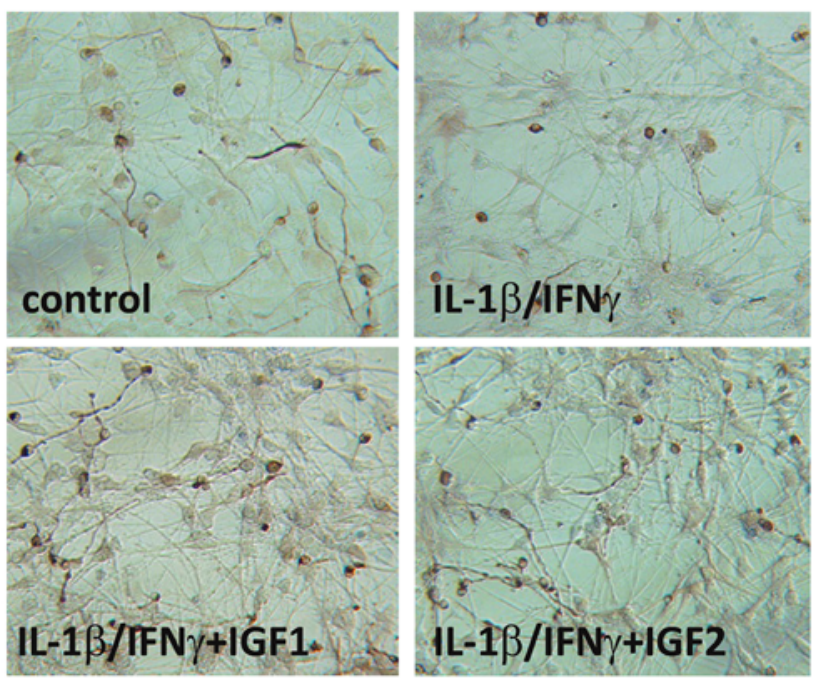

Figure 7 IGF1 or IGF2 significantly protects neurons from cytokine-induced toxicity. Mixed human fetal neuronal glial cultures were stimulated with IL-1/IFNy for 3 days to induce neurotoxicity. A subset of cultures was pre-treated with either IGF1 or IGF2 at $10 \mathrm{ng} / \mathrm{ml}$. Neuronal death was evaluated using viral dye exclusion $(\mathbf{A})$ or MAP2 immunostain $(\mathbf{B}, \mathbf{C})$ as previously described [37]. IGF1 or IGF2 reversed the neuronal dead caused by IL-1/IFNy Results are mean \pm SD from triplicate cultures, and are representative of five independent experiments with similar results. One-way ANOVA with Dunnett's multiple comparison tests. ${ }^{*} P<0.05$, ${ }^{* *} P<0.01,{ }^{* * *} P<0.001$.

expression, as for IGF1 [42-44]. Our attempts to delineate IGF2 expression in human CNS have resulted in minimal staining of brain parenchyma. There are several possibilities for this, including extremely low levels of expression and inadequate antibodies for tissue staining. Additional possibilities include rapid capture and degradation of IGF2 by the receptor IGF2R, which we found to be significantly upregulated in activated microglial cells in the CNS [29].

More importantly, we show that cultured human microglia are significant sources of IGF1 and IGF2. Mouse bone marrow macrophages and microglia have been reported to produce $\mathrm{ng} / \mathrm{ml}$ levels of IGF1 $[6,52,53]$. Furthermore, murine macrophage and microglia IGF1 production is upregulated by IL-4 or IL-13 [52], but downregulated by IFN $\gamma[6,53]$, suggesting that IGF1 production is a function of M2 activation. Yet another study of rat microglia showed that IGF1 (and IGF2) are induced by LPS [50]. In the current study, we find that human fetal microglia produce relatively low levels $(\sim 100 \mathrm{pg} / \mathrm{ml})$ of IGF1 and that this level is potently suppressed by LPS (and poly(I:C)), as well as by very high concentrations of IFN $\gamma$. The expression profile of TNF $\alpha$ mRNA in microglial culture (Figure 2D) suggests that TNF $\alpha$ might mediate the IGF1-suppressive effects of LPS, poly(I:C), and even IFNY in these cultures, establishing an interesting relationship between IGF1 and TNF $\alpha$.

Indeed, there is evidence that proinflammatory stimuli suppress neuronal growth factor production. We have recently reported that LPS potently suppresses another microglial-derived neuronal growth factor, progranulin [11]. It has also been shown that BDNF is suppressed by LPS in the rat CNS in vivo [54]. These results together establish a relationship between macrophage and microglia 
activation phenotypes and IGF1 production, and further suggest that neurotrophic growth factor production is suppressed in a proinflammatory (M1) environment but is encouraged in an M2 environment. In addition to macrophage cell types, proinflammatory cytokines have also been shown to inhibit IGF1 expression in systemic cells. For instance, IL-1 and TNF $\alpha$ suppress (growth hormoneinduced) IGF1 mRNA expression in hepatocytes $[55,56]$.

Despite extensive study, the molecular mechanism underlying regulation of IGF1 transcription is not well understood. The $5^{\prime}$ regulatory region of the IGF- 1 gene contains a cAMP response element (CRE) $[57,58]$. Human microglial IGF1 expression was increased by $\mathrm{db}$ cAMP, suggesting that IGF1 expression in these cells is also under the control of CRE. As many neurotransmitters (norepinephrine, dopamine, and so on) activate the cAMP/protein kinase A (PKA) pathway, these results suggest that IGF1 expression can be facilitated in the neural environment. Conversely, under chronic neurodegenerative conditions (such as Alzheimer's disease and Parkinson's disease), growth factors levels can be depleted, as a result of selective neurotransmitter deficiencies. The effect of proinflammatory mediators on IGF1 expression might in part be explained as a consequence of their role in cAMP/CRE activation. Together, these results indicate intriguing relationships between neural environment, growth factor production, and neuroinflammation $[59,60]$.

Regulation of IGF2 has been extensively studied in tumors, with little information available on non-neoplastic cells. IGF2 is an imprinted gene and has an important role during mouse development [16,20,25,61]. Excess IGF2 is produced during fetal stage and failure of removal of excess IGF2 due to IGF2R deficiency results in fatal organ overgrowth due to overstimulation of IGF1R. Less is known about the post-developmental role of IGF2, but in human beings, IGF2 production continues after birth. IGF2, similar to IGF1, signals through IGF1R with resulting cell survival, growth, and metabolic effects mediated by the PI3K/Akt pathways. In our investigation, IGF2 expression was uniquely upregulated by LPS (in contrast to IGF1) in human microglia, (and by IL-1 $\beta$ in astrocytes in culture), suggesting that the two IGF peptides are under different regulatory controls. Several sequences identified in the human IGF2 promoter include Sp1, Egr-1-like, C/EBP, and AP-1 sites [61], some of which are inducible by LPS. Future studies are necessary to elucidate the molecular mechanisms underlying differential microglial IGF peptide expression.

IGF1 is a well-known survival factor for many different cell types, including neurons. There is evidence that decreased IGF1 levels are correlated with impaired cognitive function and neurodegeneration in humans. For instance, increased serum TNF $\alpha$ and decreased IGF1 levels were reported in Alzheimer's patients, with the two showing a significant negative correlation [26]. In another study, CSF (but not serum) levels of IGF1 were found to be diminished in individuals with motor neuron disease [62]. Studies that directly investigated the neurotrophic effects of IGF1 are rare. IGF1, in combination with erythropoietin, has been shown to mitigate HIV gp120-induced neurotoxicity in mouse in both in vivo and in vitro models [63]. IGF1 was neuroprotective against TNFo-induced toxicity or HIV-infected cell supernatants-induced toxicity in rodent cell lines [64]. Recent studies have assessed the efficacy of exogenous IGF1 in reducing the inflammatory response of rat astrocytes [65]. In contrast to IGF1, little is known about the physiological function of IGF2 in the nervous system. In the mouse, IGF2 has recently been proposed as a critical component in memory enhancement and consolidation via promoting survival and maturation of hippocampal neurons [66,67]. In this study, using human cells, we show that IGF1R is predominantly expressed by neurons, and that recombinant IGF1 or IGF2 individually confer significant protection from cytokine-induced neuronal death and provide sustenance of MAP2 protein expression. These results together support the notion that IGF family peptides are significant survival factors for human or rodent neurons and that IGF1 and IGF2 might provide future therapeutic targets for neurodegenerative diseases.

\section{Conclusions}

In this study, we investigated whether IGF1 and IGF2 are expressed in human microglia in vivo and in vitro, and whether their expression is modulated by inflammatory cytokines. We also investigated whether IGF1 or IGF2 modulate neuronal survival. We demonstrated that IGFs are expressed in microglia and that their expression is modulated differently; for example, LPS potently suppressed IGF1 but increased IGF2. Lastly, we found that both IGF1 and IGF2 conferred strong protection against cytokine-mediated neuronal death in human fetal neuronal culture, supporting their potential future therapeutic applications in various human CNS conditions. Our results suggest that neuronal growth factors (IGF1, progranulin) are negative regulated by proinflammatory stimuli and that the negative impact of inflammation on neural growth factor production might contribute to neurodegeneration.

\footnotetext{
Abbreviations

ANOVA: analysis of variance; AP-1: activation protein-1; BDNF: brain-derived growth factor; BSA: bovine serum albumin; C/EBP: CCAAT/enhancer binding protein; CNS: central nervous system; CRE: CAMP response element; CSF: cerebrospinal fluid; DMEM: Dulbecco's modified Eagle's medium; ELISA: enzyme-linked immunosorbent assay; FBS: fetal bovine serum; GH: growth hormone; H\&E: hematoxylin and eosin; HIVE: HIV encephalitis; IFNY: interferon-gamma; IGF1: insulin-like growth factor 1; IGF2: insulin-like growth factor 2; IGF1R: insulin-like growth factor 1 receptor; IGF2R: insulinlike growth factor 2 receptor; IGFBP: insulin-like binding protein; IL-

$1 \beta$ : interleukin-1 beta; iNOS: inducible nitric oxide synthase;

LPS: lipopolysaccharide; M1: macrophage classical activation phenotype;
} 
M2: macrophage alternative activation phenotype; MGC: multinucleated giant cell; NGS: normal goat serum; PBDA: porphobilinogen deaminase; PBS: phosphate-buffered saline; PKA: protein kinase A; Q-PCR: real-time reverse-transcription PCR; TLR: toll-like receptor; TNF: tumor necrosis factor.

\section{Competing interests}

The authors declare no competing interests.

\section{Authors' contributions}

$H S, M Z, L D$, and NC performed the experiments and interpreted the data; HS and $\mathrm{SCL}$ designed the experiments, analyzed the data, and wrote the paper. All authors have read and approved the final version of the manuscript.

\section{Acknowledgements}

The authors thank the Einstein Human Fetal Tissue Repository (Dr. Brad Poulos) and the National NeuroAIDS Tissue Consortium (Manhattan HIV Brain Bank, Dr. Susan Morgello) for providing tissues for this study. We are grateful to Drs. Sanjeev Gupta and Kathleen Whitney for providing control tissue and reagents for this study, and to Drs. Scott Letendre and Howard Strickler for helpful discussions. This study was supported by the NIH grants KO1MH084705, RO1MH55477, Einstein CFAR (P30AI051519), and a pilot grant from Einstein CFAR.

\section{Received: 9 November 2012 Accepted: 3 January 2013}

Published: 12 March 2013

\section{References}

1. Hanisch UK, Kettenmann H: Microglia: active sensor and versatile effector cells in the normal and pathologic brain. Nat Neurosci 2007, 10:1387-1394.

2. Davalos D, Grutzendler J, Yang G, Kim JV, Zuo Y, Jung S, Littman DR, Dustin ML, Gan WB: ATP mediates rapid microglial response to local brain injury in vivo. Nat Neurosci 2005, 8:752-758.

3. Gowing G, Vallieres L, Julien JP: Mouse model for ablation of proliferating microglia in acute CNS injuries. Glia 2006, 53:331-337.

4. Lalancette-Hebert M, Gowing G, Simard A, Weng YC, Kriz J: Selective ablation of proliferating microglial cells exacerbates ischemic injury in the brain. J Neurosci 2007, 27:2596-2605.

5. Neumann J, Sauerzweig S, Ronicke R, Gunzer F, Dinkel K, Ullrich O, Gunzer M, Reymann KG: Microglia cells protect neurons by direct engulfment of invading neutrophil granulocytes: a new mechanism of CNS immune privilege. J Neurosci 2008, 28:5965-5975.

6. Butovsky O, Landa G, Kunis G, Ziv Y, Avidan H, Greenberg N, Schwartz A, Smirnov I, Pollack A, Jung S, Schwartz M: Induction and blockage of oligodendrogenesis by differently activated microglia in an animal model of multiple sclerosis. J Clin Invest 2006, 116:905-915.

7. Ajami B, Bennett JL, Krieger C, McNagny KM, Rossi FM: Infiltrating monocytes trigger EAE progression, but do not contribute to the resident microglia pool. Nat Neurosci 2011, 14:1142-1149.

8. Ransohoff RM: Microglia and monocytes: 'tis plain the twain meet in the brain. Nat Neurosci 2011, 14:1098-1100.

9. Gordon S: Alternative activation of macrophages. Nat Rev Immunol 2003, 3:23-35.

10. Van Ginderachter JA, Movahedi K, Hassanzadeh GG, Meerschaut S, Beschin A, Raes G, De BP: Classical and alternative activation of mononuclear phagocytes: picking the best of both worlds for tumor promotion. Immunobiology 2006, 211:487-501.

11. Suh HS, Choi N, Tarassishin L, Lee SC: Regulation of progranulin expression in human microglia and proteolysis of progranulin by Matrix Metalloproteinase-12 (MMP-12). PLoS One 2012, 7:e35115.

12. Ahmed Z, Mackenzie IR, Hutton ML, Dickson DW: Progranulin in frontotemporal lobar degeneration and neuroinflammation. J Neuroinflammation 2007, 4:7.

13. Batchelor PE, Porritt MJ, Martinello P, Parish CL, Liberatore GT, Donnan GA, Howells DW: Macrophages and microglia produce local trophic gradients that stimulate axonal sprouting toward but not beyond the wound edge. Mol Cell Neurosci 2002, 21:436-453.

14. Denis M: Human monocytes/macrophages: NO or no NO? J Leukoc Biol 1994, 55:682-684.

15. Raes G, Van den BR, De BP, Ghassabeh GH, Scotton C, Locati M, Mantovani A, Sozzani S: Arginase-1 and Ym1 are markers for murine, but not human, alternatively activated myeloid cells. J Immunol 2005, 174:6561-6562.
16. Denley A, Cosgrove $\sqcup$, Booker GW, Wallace JC, Forbes BE: Molecular interactions of the IGF system. Cytokine Growth Factor Rev 2005, 16:421-439

17. Carson MJ, Behringer RR, Brinster RL, McMorris FA: Insulin-like growth factor I increases brain growth and central nervous system myelination in transgenic mice. Neuron 1993, 10:729-740.

18. Ye P, Li L, Richards RG, DiAugustine RP, D'Ercole AJ: Myelination is altered in insulin-like growth factor-I null mutant mice. J Neurosci 2002, 22:6041-6051.

19. Camacho-Hubner C, Woods KA, Clark AJ, Savage MO: Insulin-like growth factor (IGF)-I gene deletion. Rev Endocr Metab Disord 2002, 3:357-361.

20. Fernandez AM, Torres-Aleman I: The many faces of insulin-like peptide signalling in the brain. Nat Rev Neurosci 2012, 13:225-239.

21. Duan C: Specifying the cellular responses to IGF signals: roles of IGFbinding proteins. J Endocrinol 2002, 175:41-54.

22. Bondy CA, Cheng CM: Signaling by insulin-like growth factor 1 in brain. Eur J Pharmacol 2004, 490:25-31.

23. Hawkes C, Kar S: The insulin-like growth factor-II/mannose-6-phosphate receptor: structure, distribution and function in the central nervous system. Brain Res Brain Res Rev 2004, 44:117-140.

24. Carro E, Trejo JL, Gomez-Isla T, LeRoith D, Torres-Aleman I: Serum insulinlike growth factor I regulates brain amyloid-beta levels. Nat Med 2002, 8:1390-1397.

25. Russo VC, Gluckman PD, Feldman EL, Werther GA: The insulin-like growth factor system and its pleiotropic functions in brain. Endocr Rev 2005, 26:916-943.

26. Alvarez A, Cacabelos R, Sanpedro C, Garcia-Fantini M, Aleixandre M: Serum TNF-alpha levels are increased and correlate negatively with free IGF-I in Alzheimer disease. Neurobiol Aging 2007, 28:533-536.

27. Congote LF: Monitoring insulin-like growth factors in HIV infection and AIDS. Clin Chim Acta 2005, 361:30-53.

28. Strickler HD, Fazzari M, Kovacs A, Isasi C, Napolitano LA, Minkoff H, Gange S, Young M, Sharp GB, Kaplan RC, Cohen M, Gunter MJ, Harris TG, Yu H, Schoenbaum E, Landay AL, Anastos K: Associations of insulin-like growth factor (IGF)-I and IGF-binding protein-3 with HIV disease progression in women. J Infect Dis 2008, 197:319-327.

29. Suh HS, Cosenza-Nashat M, Choi N, Zhao ML, Li JF, Pollard JW, Jirtle RL, Goldstein H, Lee SC: Insulin-like growth factor 2 receptor is an IFNgamma-inducible microglial protein that facilitates intracellular HIV replication: implications for HIV-induced neurocognitive disorders. Am J Pathol 2010, 177:2446-2458.

30. Cosenza-Nashat MA, Kim MO, Zhao ML, Suh HS, Lee SC: CD45 isoform expression in microglia and inflammatory cells in HIV-1 encephalitis. Brain Pathol 2006, 16:256-265.

31. Cosenza MA, Zhao ML, Si Q, Lee SC: Human brain parenchymal microglia express CD14 and CD45 and are productively infected by HIV-1 in HIV-1 encephalitis. Brain Pathol 2002, 12:442-455.

32. Huang GS, Brouwer-Visser J, Ramirez MJ, Kim CH, Hebert TM, Lin J, AriasPulido H, Qualls CR, Prossnitz ER, Goldberg GL, Smith HO, Horwitz SB: Insulin-like growth factor 2 expression modulates Taxol resistance and is a candidate biomarker for reduced disease-free survival in ovarian cancer. Clin Cancer Res 2010, 16:2999-3010.

33. Suh HS, Kim MO, Lee SC: Inhibition of granulocyte-macrophage colonystimulating factor signaling and microglial proliferation by anti-CD45RO: role of Hck tyrosine kinase and phosphatidylinositol 3-kinase/Akt. $\mathrm{J}$ Immunol 2005, 174:2712-2719.

34. Lee SC, Liu W, Brosnan CF, Dickson DW: Characterization of primary human fetal dissociated central nervous system cultures with an emphasis on microglia. Lab Invest 1992, 67:465-476.

35. Suh HS, Zhao ML, Rivieccio M, Choi S, Connolly E, Zhao Y, Takikawa O, Brosnan CF, Lee SC: Astrocyte indoleamine 2,3-dioxygenase is induced by the TLR3 ligand poly $(\mathrm{l}: \mathrm{C})$ : mechanism of induction and role in antiviral response. J Virol 2007, 81:9838-9850.

36. Rivieccio MA, Suh HS, Zhao Y, Zhao ML, Chin KC, Lee SC, Brosnan CF: TLR3 ligation activates an antiviral response in human fetal astrocytes: a role for viperin/cig5. J Immunol 2006, 177:4735-4741.

37. Downen M, Amaral TD, Hua LL, Zhao ML, Lee SC: Neuronal death in cytokine-activated primary human brain cell culture: role of tumor necrosis factor-alpha. Glia 1999, 28:114-127.

38. Krause D, Suh HS, Tarassishin L, Cui QL, Durafourt BA, Choi N, Bauman A, Cosenza-Nashat M, Antel JP, Zhao ML, Lee SC: The tryptophan metabolite 3-hydroxyanthranilic acid plays anti-inflammatory and neuroprotective roles during inflammation: role of hemeoxygenase-1. Am J Pathol 2011, 179:1360-1372. 
39. Tarassishin L, Suh HS, Lee SC: Interferon regulatory factor 3 plays an antiinflammatory role in microglia by activating the PI3K/Akt pathway. J Neuroinflammation 2011, 8:187.

40. Siddappa R, Martens A, Doorn J, Leusink A, Olivo C, Licht R, van Rijn L, Gaspar C, Fodde R, Janssen F, van Blitterswijk C, de Boer J: cAMP/PKA pathway activation in human mesenchymal stem cells in vitro results in robust bone formation in vivo. Proc Natl Acad Sci USA 2008, 105:7281-7286.

41. Fournier T, Riches DW, Winston BW, Rose DM, Young SK, Noble PW, Lake FR, Henson PM: Divergence in macrophage insulin-like growth factor-I (IGF-I) synthesis induced by TNF-alpha and prostaglandin E2. J Immunol 1995, 155:2123-2133.

42. Bondy C, Werner H, Roberts CT Jr, LeRoith D: Cellular pattern of type-I insulin-like growth factor receptor gene expression during maturation of the rat brain: comparison with insulin-like growth factors I and II. Neuroscience 1992, 46:909-923.

43. Han VK, D'Ercole AJ, Lund PK: Cellular localization of somatomedin (insulin-like growth factor) messenger RNA in the human fetus. Science 1987, 236:193-197.

44. Haselbacher GK, Schwab ME, Pasi A, Humbel RE: Insulin-like growth factor II (IGF II) in human brain: regional distribution of IGF II and of higher molecular mass forms. Proc Natl Acad Sci USA 1985, 82:2153-2157.

45. Komoly S, Hudson LD, Webster HD, Bondy CA: Insulin-like growth factor I gene expression is induced in astrocytes during experimental demyelination. Proc Natl Acad Sci USA 1992, 89:1894-1898.

46. Lee $\mathrm{WH}$, Clemens JA, Bondy CA: Insulin-like growth factors in the response to cerebral ischemia. Mol Cell Neurosci 1992, 3:36-43.

47. Selvamani A, Sathyan P, Miranda RC, Sohrabji F: An antagomir to microRNA Let7f promotes neuroprotection in an ischemic stroke model. PLoS One 2012, 7:e32662.

48. O'Donnell SL, Frederick TJ, Krady JK, Vannucci SJ, Wood TL: IGF-I and microglia/macrophage proliferation in the ischemic mouse brain. Glia 2002, 39:85-97.

49. Rotwein P, Burgess SK, Milbrandt JD, Krause JE: Differential expression of insulin-like growth factor genes in rat central nervous system. Proc Nat/ Acad Sci USA 1988, 85:265-269.

50. Kaur C, Sivakumar V, Dheen ST, Ling EA: Insulin-like growth factor I and II expression and modulation in amoeboid microglial cells by lipopolysaccharide and retinoic acid. Neuroscience 2006, 138:1233-1244.

51. Kihira T, Suzuki A, Kubo T, Miwa H, Kondo T: Expression of insulin-like growth factor-II and leukemia inhibitory factor antibody immunostaining on the ionized calcium-binding adaptor molecule 1-positive microglias in the spinal cord of amyotrophic lateral sclerosis patients. Neuropathology 2007, 27:257-268.

52. Wynes MW, Riches DW: Induction of macrophage insulin-like growth factor-I expression by the Th2 cytokines IL-4 and IL-13. J Immunol 2003, 171:3550-3559.

53. Arkins S, Rebeiz N, Brunke-Reese DL, Biragyn A, Kelley KW: Interferongamma inhibits macrophage insulin-like growth factor-I synthesis at the transcriptional level. Mol Endocrinol 1995, 9:350-360.

54. Zhou Y, Zhang Y, Li J, LV F, Zhao Y, Duan D, Xu Q: A comprehensive study on long-term injury to nigral dopaminergic neurons following intracerebroventricular injection of lipopolysaccharide in rats. J Neurochem 2012, 123:771-780.

55. Kelley KW: From hormones to immunity: the physiology of immunology. Brain Behav Immun 2004, 18:95-113.

56. Thissen JP, Verniers J: Inhibition by interleukin-1 beta and tumor necrosis factor-alpha of the insulin-like growth factor I messenger ribonucleic acid response to growth hormone in rat hepatocyte primary culture. Endocrinology 1997, 138:1078-1084.

57. Thomas MJ, Umayahara Y, Shu H, Centrella M, Rotwein P, McCarthy TL: Identification of the CAMP response element that controls transcriptional activation of the insulin-like growth factor-I gene by prostaglandin E2 in osteoblasts. J Biol Chem 1996, 271:21835-21841.

58. Hatey F, Langlois I, Mulsant P, Bonnet A, Benne F, Gasser F: Gonadotropins induce accumulation of insulin-like growth factor I mRNA in pig granulosa cells in vitro. Mol Cell Endocrinol 1992, 86:205-211.

59. Feinstein DL, Heneka MT, Gavrilyuk V, Dello RC, Weinberg G, Galea E: Noradrenergic regulation of inflammatory gene expression in brain Neurochem Int 2002, 41:357-365.

60. Lee SC, Collins M, Vanguri P, Shin ML: Glutamate differentially inhibits the expression of class II MHC antigens on astrocytes and microglia. J Immunol 1992, 148:3391-3397.
61. Zarrilli R, Bruni CB, Riccio A: Multiple levels of control of insulin-like growth factor gene expression. Mol Cell Endocrinol 1994, 101:R1-R14

62. Bilic E, Bilic E, Rudan I, Kusec V, Zurak N, Delimar D, Zagar M: Comparison of the growth hormone, IGF-1 and insulin in cerebrospinal fluid and serum between patients with motor neuron disease and healthy controls. Eur J Neurol 2006, 13:1340-1345.

63. Kang YJ, Digicaylioglu M, Russo R, Kaul M, Achim CL, Fletcher L, Masliah E, Lipton SA: Erythropoietin plus insulin-like growth factor-I protects against neuronal damage in a murine model of human immunodeficiency virusassociated neurocognitive disorders. Ann Neurol 2010, 68:342-352.

64. Ying WJ, Peruzzi F, Lassak A, Del VL, Radhakrishnan S, Rappaport J, Khalili K, Amini S, Reiss K: Neuroprotective effects of IGF-I against TNFalphainduced neuronal damage in HIV-associated dementia. Virology 2003, 305:66-76.

65. Bellini MJ, Herenu CB, Goya RG, Garcia-Segura LM: Insulin-like growth factor-I gene delivery to astrocytes reduces their inflammatory response to lipopolysaccharide. J Neuroinflammation 2011, 8:21.

66. Chen DY, Stern SA, Garcia-Osta A, Saunier-Rebori B, Pollonini G, BambahMukku D, Blitzer RD, Alberini CM: A critical role for IGF-II in memory consolidation and enhancement. Nature 2011, 469:491-497.

67. Agis-Balboa RC, Arcos-Diaz D, Wittnam J, Govindarajan N, Blom K, Burkhardt S, Haladyniak U, Agbemenyah HY, Zovoilis A, Salinas-Riester G, Opitz L, Sananbenesi F, Fischer A: A hippocampal insulin-growth factor 2 pathway regulates the extinction of fear memories. EMBO J 2011, 30:4071-4083.

doi:10.1186/1742-2094-10-37

Cite this article as: Suh et al:: Insulin-like growth factor 1 and 2 (IGF1, IGF2) expression in human microglia: differential regulation by inflammatory mediators. Journal of Neuroinflammation 2013 10:37.

\section{Submit your next manuscript to BioMed Central and take full advantage of:}

- Convenient online submission

- Thorough peer review

- No space constraints or color figure charges

- Immediate publication on acceptance

- Inclusion in PubMed, CAS, Scopus and Google Scholar

- Research which is freely available for redistribution 